\title{
Bioleaching of copper from waste printed circuit boards by bacteria-free cultural supernatant of iron-sulfur-oxidizing bacteria
}

\author{
Weijin Wu, Xiaocui Liu, Xu Zhang ${ }^{*}$, Minglong Zhu and Wensong Tan ${ }^{*}$
}

\begin{abstract}
Background: The toxicity of waste printed circuit boards (PCBs) to bacteria was considered as the major limitation in bioleaching of copper from PCBs. To reduce the toxicity of PCBs, copper extraction from PCBs was investigated using bacteria-free cultural supernatant from some metallurgical microbial consortium, whose predominant organisms were Leptospirillum ferriphilum and Sulfobacillus thermosulfidooxidans.

Results: About 100\% copper was recovered in $2 \mathrm{~h}$ from $5 \mathrm{~g} / \mathrm{L} \mathrm{PCBs}$ by bacteria-free cultural supernatant. The result indicated that the indirect non-contact mechanism was the predominant mechanism in bioleaching of copper from PCBs. It was not necessary for bacteria to exist in copper extraction. In addition, the role of bacteria was most likely to regenerate $\mathrm{Fe}^{3+}$ as an oxidant. Furthermore, the biooxidation of $\mathrm{Fe}^{2+}$ to $\mathrm{Fe}^{3+}$ was determined as the rate-limited step in bioleaching of copper from PCBs. In addition, the biooxidation activity of bacteria would be strongly inhibited by the toxicity of PCBs.

Conclusion: The separation of bacteria from the PCBs probably was the optimum way to avoid the negative effect of PCBs. Accordingly, a biooxidation-leaching-separation cycle was designed to avoid the toxicity of PCBs. Eventually, 93.4\% of copper was recovered in total from $100 \mathrm{~g} / \mathrm{L} \mathrm{PCB} \mathrm{concentrates} \mathrm{in} 9$ days.
\end{abstract}

Keywords: Wasted printed circuit boards, Bioleaching, Leptospirillum ferriphilum and Sulfobacillus thermosulfidooxidans, Biooxidation-leaching-separation cycle

\section{Background}

With the rapid development of electronic and electrical industries, more and more new electronic products are produced. When these electronic products reach their service life, a large number of e-wastes will be generated. It was estimated that about 20-25 million tons of e-waste were produced every year in the world (Robinson 2009). Therefore, it is urgent to dispose these e-wastes. As the basic part of electronic equipment, PCBs have been increasing sharply with the increment of e-wastes. PCBs contained varieties of hazardous organic and inorganic substances which required special treatment to avoid environmental contamination (Robinson 2009). In addition, PCBs contained several valuable metals and

\footnotetext{
*Correspondence: zhangxu@ecust.edu.cn; wstan@ecust.edu.cn State Key Laboratory of Bioreactor Engineering, East China University of Science and Technology, Shanghai, China
}

precious metals with quantities higher than those in some ores (Ilyas and Lee 2014). Therefore, the recovery of valuable metals from PCBs is profitable. Various processes, such as mechanical (Meng et al. 2017), pyrometallurgical (Jung et al. 2017), hydrometallurgical (Pant et al. 2012). and biometallurgical (Mrážiková et al. 2016; Priya and Hait 2017) process, have been employed for the recovery of metals from PCBs.

The biometallurgical process is usually referred as bioleaching. Bioleaching is a promising technology which utilizes microorganisms to recover metals from lowgrade ores and e-waste (Hong and Valix 2014). Benefiting from lower operational cost and energy requirements in metal recovery, bioleaching has drawn more and more attention. Chemolithoautotrophs bacteria are commonly used for metal recovery from e-waste, such as Acidithiobacillus ferrooxidans, Leptospirillum ferrooxidans, 
Acidithiobacillus thiooxidans, and so on (Erüst et al. 2013). Those bacteria which use $\mathrm{CO}_{2}$ as carbon source and inorganic compounds ( $\mathrm{Fe}^{2+}$ and reduced $\mathrm{S}$ ) as energy source utilize their ability to facilitate metal dissolution through a series of biooxidants and bioleaching reactions.

The direct and indirect biooxidation are the two mechanism of bioleaching of ore. Usually, indirect biooxidation mechanism has been accepted by most researchers (Liu et al. 2017). The indirect biooxidation mechanism includes contact and non-contact biooxidation mechanisms (Jadhav and Hocheng 2013). In contact mechanism, bacteria would adhere to ore and form a biofilm between bacteria and ore. Inside this biofilm, $\mathrm{Fe}^{2+}$ is oxidized by bacteria to $\mathrm{Fe}^{3+}$ and the ore is dissolved by $\mathrm{Fe}^{3+}$ (Liu et al. 2017). It has been proved that the formation of biofilm is important in bioleaching of ore (More et al. 2014). The concentration of ferric iron and $\mathrm{H}^{+}$in biofilm is much higher than that in solution, which could greatly increase the dissolution rate of ores (Coram and Rawlings 2002). In non-contact mechanism, the bacteria are no need to adhere to the ore. In addition, the $\mathrm{Fe}^{3+}$ which is produced by bacteria plays key role in the dissolution of ore.

Usually, the indirect contact mechanism is regarded as the mechanism of bioleaching of PCBs (Silva et al. 2015). In addition, the mechanism of bioleaching of copper from $\mathrm{PCBs}$ is present as follows:

$$
\begin{aligned}
& \mathrm{Fe}^{2+}+\mathrm{O}_{2}+4 \mathrm{H}^{+} \stackrel{\text { Bacteria }}{\longrightarrow} \mathrm{Fe}^{3+}+2 \mathrm{H}_{2} \mathrm{O} \\
& 2 \mathrm{Fe}^{3+}+\mathrm{Cu} \rightarrow 2 \mathrm{Fe}^{2+}+\mathrm{Cu}^{2+} .
\end{aligned}
$$

In this process, the dissolution of copper from PCBs can be divided into two phases. In the first phase, the ferrous ions are oxidized by bacteria to generate ferric ions. In the second phase, copper is mobilized from the PCBs by the ferric ions, and the ferric ions are reduced to ferrous ions. Therefore, a cycle between $\mathrm{Fe}^{3+}$ and $\mathrm{Fe}^{2+}$ is formed and copper is leached out (Yang et al. 2009).

Many researchers have studied the process of bioleaching of copper from PCBs (Arshadi and Mousavi 2015; Mrážiková et al. 2016). However, few process of bioleaching of PCBs was applied commercially for the reasons of long leaching time and low leaching efficiency.

The toxicity of the PCBs which can affect the growth of bacteria has been thought to be the major reason of low-efficient leaching (Yang et al. 2014). The activity of bacteria could be inhibited immediately by addition of elemental metal ions $\left(\mathrm{Cu}^{2+}, \mathrm{Cr}^{3+}, \mathrm{Ni}^{+}, \mathrm{Sn}^{2+}\right.$, and $\left.\mathrm{Zn}^{2+}\right)$ (Bryan et al. 2015). The presence of non-metallic components in PCBs showed the bacterial toxicity in the bioleaching process (Zhu et al. 2011).

Various methods were used to reduce the toxic effect of PCBs on bacteria. The reducing of the toxicity of PCBs and the increasing of the activity and resistance of bacteria in bioleaching of PCBs were always considered. Metal concentrates of PCBs were used to reduce the toxic effects of non-metallic components in PCBs on bacteria (Zhu et al. 2011). The negative impact of PCBs on bacteria was decreased by controlling the particle size of PCBs (Zhu et al. 2011). High oxidation activity of strains was screened to bioleach the PCBs (Bas et al. 2013; Nie et al. 2015). Mixed culture whose performance was better than that of single bacteria was used (Jiang et al. 2017; Liang et al. 2013). The tolerance of bacteria could be improved by acclimatization of bacteria to the condition of PCBs (Arshadi and Mousavi 2014). A few examples which bioleaching PCBs by different kinds of bacteria are summarized in Table 1 (shows some examples about bioleaching PCBs by different kinds of bacteria). As far as we know, few report has studied the bioleaching of PCBs using a mixed culture of Leptospirillum ferriphilum and Sulfobacillus thermosulfidooxidans.

Furthermore, two-step process was used to mitigate the toxic effect of PCBs (Arshadi and Mousavi 2015; Xiang et al. 2010). In addition, response surface methodology (RSM) was used to optimize the parameters of bioleaching of PCBs (Arshadi and Mousavi 2015). However, the activity of bacteria is inevitably affected by the contact of PCBs. Due to the toxicity of PCBs, the indirect non-contact mechanism may be the better mechanism for bioleaching of copper from PCBs. To the best of our knowledge, few studies have reported the bioleaching of copper from PCBs using bacteria-free cultural supernatant.

The purpose of the present study is to prove that if it is feasible to achieve the bioleaching of copper from PCBs using bacteria-free cultural supernatant. In addition, the biooxidation process and chemical-leaching process during the whole bioleaching process of PCBs were investigated and compared to confirm the role of bacteria in bioleaching of PCBs. Besides, the toxic effect of PCBs on bacteria was investigated. Finally, a continuous biooxidation-leaching-separation cycle with high leaching efficiency was designed to mitigate the toxic effect of PCBs on bacteria.

\section{Methods}

\section{Waste printed circuit boards and pyrite samples}

The waste printed circuit boards were obtained from a local electronics company in Shanghai, China. The scraps of PCBs were first cut into small pieces manually, then crushed by the high-speed universal pulverizer for $2 \mathrm{~min}$, and finally sieved. The power with the size below 40 mesh was collected and subjected to hydraulic sorting so as to remove the non-metallic components from PCBs' powder. The left part then was air-dried. 
Table 1 Bioleaching of metals from PCBs

\begin{tabular}{|c|c|c|c|}
\hline References & Microorganisms & Recovery and conditions & Characterization of microorganisms \\
\hline Arshadi and Mousavi (2015) & Acidithiobacillus ferrooxidans & $\begin{array}{l}\text { 100\% Cu and Ni in } 20 \text { days at } 8.5 \mathrm{~g} / \mathrm{L} \\
\text { pulp density }\end{array}$ & Mesophiles bacteria \\
\hline Isildar et al. (2016) & $\begin{array}{l}\text { Acidithiobacillus ferrivorans and Acidith- } \\
\text { iobacillus thiooxidans }\end{array}$ & $\begin{array}{l}98.4 \% \text { Cu in } 7 \text { days at } 10 \mathrm{~g} / \mathrm{L} \text { pulp } \\
\text { density }\end{array}$ & Mesophiles bacteria \\
\hline Ilyas et al. (2013) & $\begin{array}{l}\text { Sulfobacillus thermosulfidooxidans and } \\
\text { Thermoplasma acidophilum }\end{array}$ & $\begin{array}{r}74 \% \mathrm{Zn}, 68 \% \mathrm{Al}, 85 \% \mathrm{Cu}, 78 \% \mathrm{Ni} \text { in } \\
165 \text { days at } 100 \mathrm{~g} / \mathrm{L} \text { pulp density }\end{array}$ & Moderately thermophilic bacteria \\
\hline Rodrigues et al. (2015) & Sulfobacillus thermosulfidooxidans & $\begin{array}{l}85 \% \text { Cu in } 8 \text { days at } 25 \mathrm{~g} / \mathrm{L} \text { pulp } \\
\text { density }\end{array}$ & Moderately thermophilic bacteria \\
\hline Zhu et al. (2011) & Mixed culture of acidophilic bacteria & $\begin{array}{l}96.8 \% \mathrm{Cu} \text { in } 45 \mathrm{~h}, 88.2 \% \mathrm{Al} \text { and } 91.6 \% \\
\mathrm{Zn} \text { in } 98 \mathrm{~h} \text { at } 12 \mathrm{~g} / \mathrm{L} \text { pulp density }\end{array}$ & Mesophiles bacteria \\
\hline Vestola et al. (2010) & $\begin{array}{l}\text { Acidithiobacillus sp. and Leptospirillum } \\
\text { sp. }\end{array}$ & $\begin{array}{l}\text { 100\% Cu and Ni in } 42 \text { days at } 10 \mathrm{~g} / \mathrm{L} \\
\text { pulp density }\end{array}$ & Mesophiles bacteria \\
\hline Current work & Microbial consortium & $\begin{array}{l}\text { 93.4\% Cu in } 9 \text { days at } 100 \mathrm{~g} / \mathrm{L} \text { pulp } \\
\text { density }\end{array}$ & Moderately thermophilic bacteria \\
\hline
\end{tabular}

The PCB concentrates was digested with aqua regia, cooled, and then diluted to appropriate concentration range using deionized water. The metal content of digestion solution was determined using inductively coupled plasma-optical emission spectrometry (ICP-OES, Agilent 725ES). The metal content of PCB concentrates was found to be copper $(65.0 \%)$, aluminum $(0.85 \%)$, iron $(0.23 \%)$, nickel $(<0.01 \%)$, lead $(0.02 \%)$, and zinc $(<0.01 \%)$. The experiments were conducted in triplicates. All data presented in this study were obtained from triplicate experiments with a standard error of $\leq \pm 0.05$.

The pyrite samples were kindly supplied by one gold mine Co. Ltd., P. R. China, which containing $30 \pm 0.5 \%$ Fe, $28 \pm 0.3 \% \mathrm{~S}$, and $3 \pm 0.1 \%$ As. The sample was sieved to obtain a particle size distribution between 63 and $90 \mu \mathrm{m}$.

\section{Bacteria and growth media}

Microbial consortium was preserved in our laboratory. The organisms were studied by analyzing the $\mathrm{V} 4$ region of $16 \mathrm{~S}$ rDNA using a high-throughput DNA sequencing technique. The result is shown in Fig. 1. In addition, the predominant organisms were Leptospirillum ferriphilum and Sulfobacillus thermosulfidooxidans. The adjusted medium developed from the $9 \mathrm{~K}$ media was used for the bacterial culture. The medium contained $3.0 \mathrm{~g}$ $\left(\mathrm{NH}_{4}\right)_{2} \mathrm{SO}_{4}, 0.1 \mathrm{~g} \mathrm{KCl}, 0.5 \mathrm{~g} \mathrm{MgSO}_{4} \cdot 7 \mathrm{H}_{2} \mathrm{O}, 0.5 \mathrm{~g} \mathrm{~K}_{2} \mathrm{HPO}_{4}$, $0.01 \mathrm{~g} \mathrm{Ca}\left(\mathrm{NO}_{3}\right)_{2}$, and $74.5 \mathrm{~g} \mathrm{FeSO}_{4} \cdot 7 \mathrm{H}_{2} \mathrm{O}$ in $1 \mathrm{~L}$ distilled water. All chemical reagents were of analytical grade.

\section{Copper extraction from PCBs using bacteria-free cultural supernatant}

The adjusted $9 \mathrm{~K}$ medium $\left(15 \mathrm{~g} / \mathrm{L} \mathrm{Fe}^{2+}\right)$ was added into $250 \mathrm{~mL}$ Erlenmeyer flask with $10 \%$ inoculum, cultivated at the initial $\mathrm{pH}$ of $0.9,42{ }^{\circ} \mathrm{C}$ and $200 \mathrm{rpm}$ for several hours until the ferrous ion was totally oxidized to ferric, then filtered to remove precipitation and sterilized by filtration using $0.22 \mu \mathrm{m}$ membrane (Merck Millipore Ltd). 5, 10, and $15 \mathrm{~g} / \mathrm{L} \mathrm{PCBs}$ were placed into the filtrate, respectively. In addition, $15 \mathrm{~g} / \mathrm{L}$ ferric sulfate solution, pure water, and pure medium without $\mathrm{FeSO}_{4} \cdot 7 \mathrm{H}_{2} \mathrm{O}$ were set as control. The experiments were carried out at the initial $\mathrm{pH}$ of $1.2,55^{\circ} \mathrm{C}$, and $200 \mathrm{rpm}$. All experiments were done in orbital shaker incubators. Samples were collected intervals to analyze $\mathrm{pH}$, the concentrations of ferrous and copper ions. The experiments were conducted in triplicate.

\section{The effect of PCBs on bacterial oxidation activity}

Different amounts of PCBs were added into the adjusted $9 \mathrm{~K}$ medium with $10 \%$ inoculum to obtain the initial concentrations of PCBs at $0,5,10$, and $15 \mathrm{~g} / \mathrm{L}$. The culture was cultivated at the initial $\mathrm{pH}$ of $0.9,32{ }^{\circ} \mathrm{C}$, and $180 \mathrm{rpm}$. Samples were collected intervals to analyze $\mathrm{pH}$, Eh, and the concentrations of ferrous ions. The experiments were conducted in triplicate.

\section{The role of pyrite on bacterial oxidation of ferrous ions}

For the purpose of immobilization of bacteria, pyrite was introduced into the process of bacterial oxidation of ferrous ions. Five grams pyrite was added into $90 \mathrm{~mL}$ adjusted $9 \mathrm{~K}$ medium with $10 \%$ inoculum. The culture was cultivated at $42{ }^{\circ} \mathrm{C}$ and $180 \mathrm{rpm}$. After the ferrous ion in the solution was exhausted, the solution was stood and filtered to remove the supernatant. Then, $100 \mathrm{ml}$ fresh adjusted $9 \mathrm{~K}$ medium was injected into the precipitation for the bacterial culture. Once the ferrous ion was exhausted, the solution was stood, filtered. In addition, the fresh medium was injected again. Samples of bioleaching solution were collected to analyze $\mathrm{pH}$, Eh, 

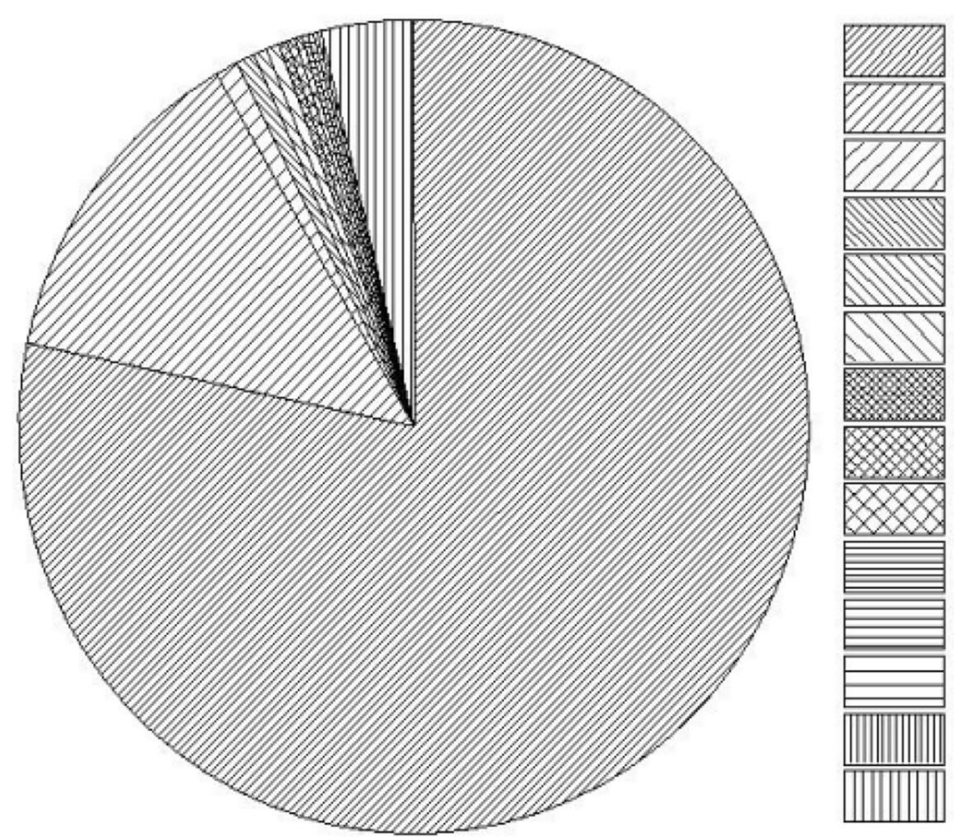

Leptospirillum

Sulfobacillus

Sporanaerobacter

Flexibacter

Tepidanaerobacter

Cerasibacillus

Lactococcus

Caldicoprobacter

Bacillus

Ureibacillus

Truepera

Streptococcus

Cyclobacterium

others

Fig. 1 Construction of the microbial consortium

and the concentrations of $\mathrm{Fe}^{2+}$ and $\mathrm{Fe}^{3+}$. The experiments were conducted in triplicate.

\section{The biooxidation-leaching-separation cycle}

A new biooxidation-leaching-separation cycle was designed to bioleaching of PCBs. The details of the cycle were as follows: in the Biooxidation process, it consisted of three parts: adjusted 9k medium, the mixed bacterial culture, and pyrite. The bacteria were absorbed on pyrite. In addition, $\mathrm{Fe}^{2+}$ in the medium was oxidized to $\mathrm{Fe}^{3+}$ by bacteria. After $\mathrm{Fe}^{2+}$ was exhausted, the solution was left to stand. The supernatant which contained high concentration of $\mathrm{Fe}^{3+}$ was used to the Leaching process. In addition, the precipitate which was pyrite and bacteria was used to oxidize $\mathrm{Fe}^{2+}$ again. In the leaching process, the supernatant from biooxidation process was used to leaching PCBs for the recovery of copper. After the reaction finished, the solution contained copper ion was filtered to be used to the Separation process. In the separation process, the copper ion in the solution was recovered by iron power. In addition, the solution, which obtained $\mathrm{Fe}^{2+}$, was returned to the biooxidation process again.

To prove the feasibility of the cycle, several experiments were designed. $100 \mathrm{~mL}$ of adjusted $9 \mathrm{~K}$ medium was oxidized by bacteria first. And then, the supernatant was used to leaching $15 \mathrm{~g} / \mathrm{L}$ PCBs. After the leaching process was accomplished, the solution was filtered. Then, $\mathrm{Cu}^{2+}$ in the solution was separated by displacement of iron power. Finally, the solution was diluted to the concentration of $15 \mathrm{~g} / \mathrm{L} \mathrm{Fe}{ }^{2+}$ for the bacterial oxidation again. A control which fresh adjusted 9K medium $(15 \mathrm{~g} / \mathrm{L}$ $\mathrm{Fe}^{2+}$ ) was added was set. The cultures were cultivated at the initial $\mathrm{pH}$ of $0.9,32{ }^{\circ} \mathrm{C}$, and $180 \mathrm{rpm}$. Samples were collected every $6 \mathrm{~h}$ to analyze $\mathrm{pH}$, Eh, and the concentrations of $\mathrm{Fe}^{2+}$ and $\mathrm{Fe}^{3+}$. The experiments were conducted in triplicate.

The bacterial oxidation activity might be affected by some metals such as $\mathrm{Ni}, \mathrm{Al}$, and $\mathrm{Zn}$ which were mobilized from PCBs. Therefore, the effect of the copper $(0$, $1,3,5$, and $10 \mathrm{~g} / \mathrm{L}), \mathrm{Ni}(0,1,5,10$, and $20 \mathrm{~g} / \mathrm{L}), \mathrm{Al}(0,1,5$, 10 , and $20 \mathrm{~g} / \mathrm{L})$, and $\mathrm{Zn}(0,1,5,10$, and $20 \mathrm{~g} / \mathrm{L})$ on bacterial oxidation of $15 \mathrm{~g} / \mathrm{L} \mathrm{Fe} \mathrm{Fe}^{2+}$ was test. Samples were collected every $6 \mathrm{~h}$ to analyze $\mathrm{pH}$, Eh, and the concentrations of $\mathrm{Fe}^{2+}$ and $\mathrm{Fe}^{3+}$. The experiments were conducted in triplicate.

\section{Validation test}

The effect of increase of cycles on bacterial oxidation of $\mathrm{Fe}^{2+}$ was studied. $100 \mathrm{~mL}$ of adjusted $9 \mathrm{~K}$ medium was oxidized by bacteria firstly. And then, the supernatant was used to leaching PCBs. The solution was filtered after the bioleaching process was accomplished. $\mathrm{Cu}^{2+}$ in the leachate was separated by displacement of iron power. Finally, the solution was diluted to the concentration of $15 \mathrm{~g} / \mathrm{L} \mathrm{Fe}^{2+}$ for the bacterial oxidation again. Totally, $100 \mathrm{~g} / \mathrm{L}$ of PCBs were disposed with nine times of cycles. The tactic was as follows: the addition of PCBs was $15 \mathrm{~g} / \mathrm{L}$ 
at the first 4 cycles and $10 \mathrm{~g} / \mathrm{L}$ at the next 4 cycles, and $0 \mathrm{~g} / \mathrm{L}$ PCBs at the last cycle for completely reaction. Samples were collected to analyze $\mathrm{pH}$, Eh, and the concentrations of $\mathrm{Fe}^{2+}, \mathrm{Fe}^{3+,}$ and $\mathrm{Cu}^{2+}$.

\section{Analytical methods}

The $\mathrm{pH}$ and redox potential was measured by a $\mathrm{pH}$ meter and Eh meter (Mettler model FE20). The concentration of ferrous iron was determined by titration with potassium dichromate in the presence of the indicator $\mathrm{N}$-phenylanthranilic acid. Copper ion concentration was determined by atomic absorption spectrometer (Analytic Jena AG, Germany). The concentration of $\mathrm{Fe}^{3+}$ was determined by the titration of EDTA at pH 2 in the presence of sulphosalicylic acid as an indicator. All experiments were done in orbital shaker incubators.

\section{Results and discussion}

\section{Copper extraction from PCBs using bacteria-free cultural supernatant}

A microbial consortium which Leptospirillum ferriphilum and Sulfobacillus thermosulfidooxidans were the predominant organisms was used to produce the supernatant. The microbial consortium had been adapted in metal-contained medium for several years. In addition, the metal tolerance of the species in the literature and the microbial consortium used in this paper are shown in Table 2. It was indicated that the mixed culture used in this study had stronger metal tolerance.

Figure 2 shows the leaching results of copper from PCBs by bacteria-free cultural supernatant. As shown in Fig. 2a, the addition of PCBs would cause the rise of $\mathrm{pH}$. It indicated that the PCBs was alkaline, and the result was consistent with Yang et al. (2009) and Arshadi and Mousavi (2014). Figure 2c demonstrates that the leaching reactions mainly occurred at the first $2 \mathrm{~h}$. In addition, almost $100 \%$ copper was dissolved by bacteria-free cultural supernatant when adding $5 \mathrm{~g} / \mathrm{L}$ PCBs. The result indicated that the copper in the PCBs was released due to chemical oxidation by ferric ion. During the chemical oxidation process, $\mathrm{Fe}^{3+}$ (strong oxidizing agent) was constantly converted to $\mathrm{Fe}^{2+}$, and it was confirmed by Fig. 2b. In addition, with the amount of PCBs increasing, the recovery of copper gradually decreased. It was related to the consumption of ferric iron in bacteria-free cultural supernatant. In addition, the consumption of $\mathrm{Fe}^{3+}$ is shown in Fig. 2d. After $2 \mathrm{~h}$, the content of ferric iron in the solution had been reduced to a low level under the condition of $15 \mathrm{~g} / \mathrm{L}$ PCBs. Therefore, the residual copper in the PCBs could not be dissolved quickly.

To verify that the oxidation of $\mathrm{Fe}^{3+}$ was the predominant mechanism of the copper extraction from PCBs by bacteria-free cultural supernatant, ferric sulfate solution, bacteria-free cultural supernatant, pure water, and pure media were used to leach $15 \mathrm{~g} / \mathrm{L}$ PCBs, and the result is shown in Fig. 3. There was a little copper extracted by pure water and pure medium in the initial $\mathrm{pH}$ of 1.2 , which indicated that in this process, the role of acid leaching was not significant. However, the copper recovery of bacteria-free cultural supernatant and ferric sulfate solution was similar and much higher than that of pure water and pure medium which confirmed that the copper in PCBs was dissolved by the oxidation of $\mathrm{Fe}^{3+}$. The result indicated that the indirect non-contact mechanism was the predominant mechanism in bioleaching of copper from PCBs. It was also demonstrated that there was no need for bacteria to contact with PCBs for the extraction of copper. In addition, the role of bacteria in bioleaching of PCBs was most likely to regenerate $\mathrm{Fe}^{3+}$ as oxidant. Jadhav and Hocheng (2013) investigated silver extraction from spent silver oxide-zinc button cell battery using Acidithiobacillus ferrooxidans, and considered indirect non-contact leaching was the predominant mechanism for metal solubilization. Kim et al. (2005) demonstrated indirect non-contact leaching performed better than direct leaching in bioleaching of cadmium and nickel from synthetic sediments.

\section{The toxic effect of PCBs on bacterial oxidation activity}

It had been confirmed in the "Copper extraction from PCBs using bacteria-free cultural supernatant" section that the chemical-leaching process (Eq. 2) could be directly achieved by bacteria-free cultural supernatant. However, the bacteria were required to participate in the biooxidation of $\mathrm{Fe}^{2+}$ to $\mathrm{Fe}^{3+}$ (Eq. 1). To obtain the optimum oxidation rate of bacteria (without PCBs), growth conditions of the mixed bacteria used in the experiment were optimized (data not show). Finally, the optimum

Table 2 Range of metal tolerance of different kinds of bacteria

\begin{tabular}{|c|c|c|}
\hline Reference & Bacteria & The maximum metal concentration whereby metabolic activity still occurs \\
\hline Tian et al. (2007) & L. ferriphilum & $\mathrm{Ni}^{2+}(30-40 \mathrm{mM}), \mathrm{Zn}^{2+}(20-30 \mathrm{mM}), \mathrm{Co}^{2+}(5-10 \mathrm{mM}), \mathrm{Cu}^{2+}(<5 \mathrm{mM})$ and $\mathrm{Cd}^{2+}(<5 \mathrm{mM})$ \\
\hline Dopson et al. (2003) & S. thermosulfidooxidans & $6 \mathrm{mMCu}^{2+}, 43 \mathrm{mM} \mathrm{Zn}^{2+}$, and $5 \mathrm{mM} \mathrm{Ni}^{2+}$ \\
\hline Hallmann et al. (1992) & L.ferrooxidans & $\mathrm{Al}^{3+}(278 \mathrm{mM}), \mathrm{Co}^{2+}(17.0 \mathrm{mM}), \mathrm{Cu}^{2+}(391 \mathrm{mM}), \mathrm{Mn}^{2+}(546 \mathrm{mM}), \mathrm{Ni}^{2+}(127 \mathrm{mM})$, and $\mathrm{Zn}^{2+}(461 \mathrm{mM})$ \\
\hline Current work & Microbial consortium & $\mathrm{Al}^{3+}(1049 \mathrm{mM}), \mathrm{Zn}^{2+}(1046 \mathrm{mM}), \mathrm{Ni}^{2+}(681 \mathrm{mM})$ and $\mathrm{Cu}^{2+}(781 \mathrm{mM})$ \\
\hline
\end{tabular}




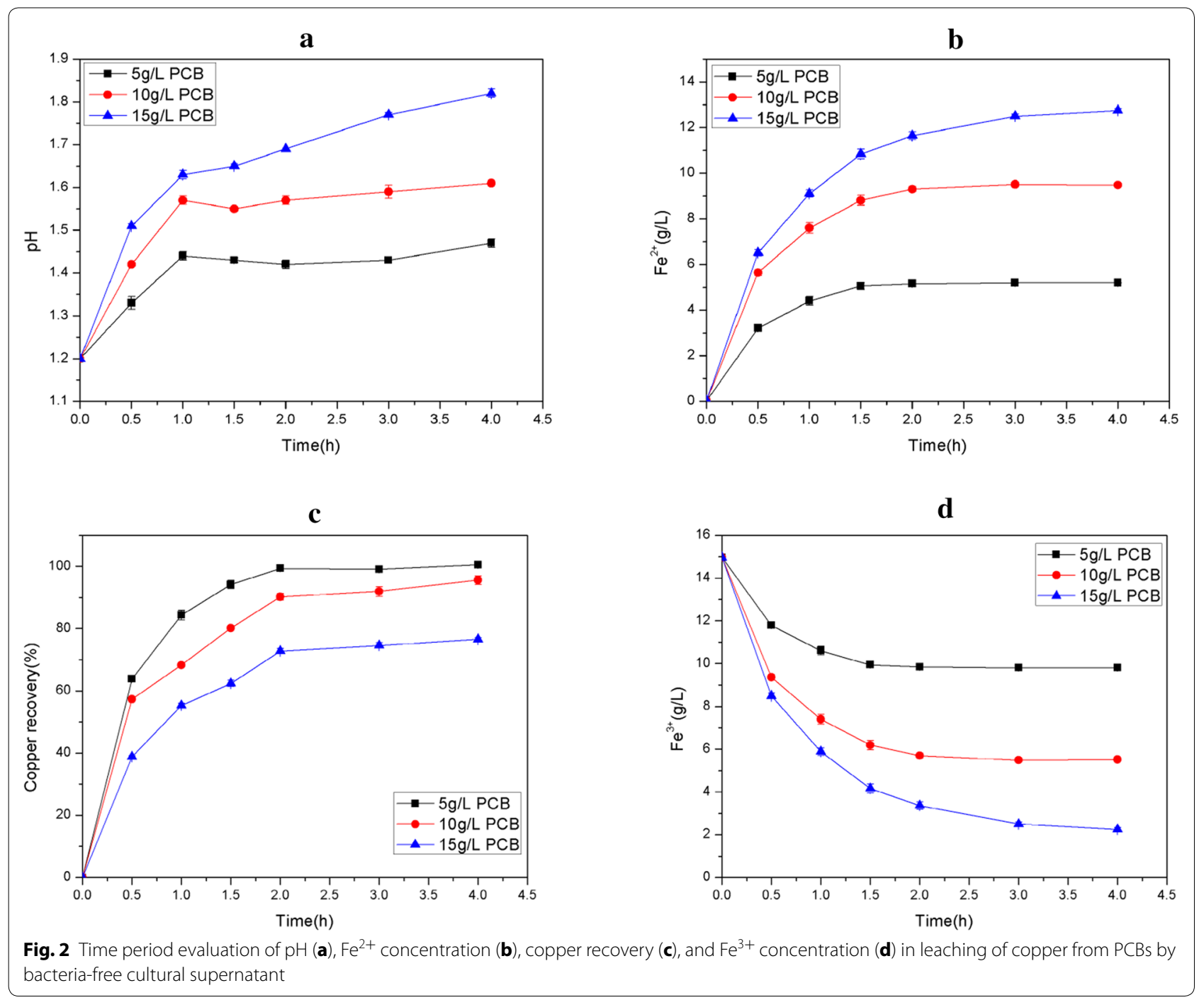

biooxidation rate was obtained at the initial $\mathrm{pH}$ of 0.9 , the temperature of $32{ }^{\circ} \mathrm{C}$ and the initial $\mathrm{Fe}^{2+}$ concentration of $15 \mathrm{~g} / \mathrm{L}$. As shown in Fig. 4c, the complete biooxidation of $15 \mathrm{~g} / \mathrm{L} \mathrm{Fe}^{2+}$ required $24 \mathrm{~h}$ in $0 \mathrm{~g} / \mathrm{L}$ PCBs, and the rates of consumption of $\mathrm{Fe}^{2+}$ were $0.5833 \mathrm{~g} / \mathrm{L}$ h. However, as shown in Fig. 2c, it only took $2 \mathrm{~h}$ for the bacteria-free cultural supernatant $\left(15 \mathrm{~g} / \mathrm{L} \mathrm{Fe}^{3+}\right)$ to leach copper from $15 \mathrm{~g} / \mathrm{L}$ PCBs. In addition, the formation rate of $\mathrm{Fe}^{2+}$ was $6.69 \mathrm{~g} / \mathrm{L} \mathrm{h}$. This meant that the rate of Eq. (2) was 11.47 times faster than that of Eq. (1). This demonstrated that the biooxidation of $\mathrm{Fe}^{2+}$ was the rate-determining step in bioleaching of copper from PCBs.

The effect of different amounts of PCBs on bacterial oxidation of $\mathrm{Fe}^{2+}$ is shown in Fig. 4. As shown in Fig. 4a, the $\mathrm{pH}$ in solution increased with the addition of PCBs. In the process of bioleaching of PCBs, the rise of $\mathrm{pH}$ was caused by the following two reasons: (1) Eq. (1) shows that the oxidation of ferrous ions by bacteria was an acidconsuming process. When the amount of the PCBs was increased, more ferric ions were required to be produced by bacteria to leaching copper from PCBs. Therefore, more acid was consumed. (2) The PCBs was alkaline in nature. As the amount of PCBs increased, more acid was needed to neutralize the alkaline substance in PCBs. The optimum growth $\mathrm{pH}$ of the mixed culture was between 0.9 and 2.0, so the experimental conditions ( $\mathrm{pH} 1-2)$ did not exceed the optimum range of bacterial growth. The change of Eh is shown in Fig. 4b. Ballor et al. (2006) demonstrated that the Eh, which was a direct function of the relative concentrations of ferric and ferrous iron, could be used to indicate bacterial activity. As shown in Fig. 4b, Eh quickly increased from 400 to $650(\mathrm{mV})$ in $0 \mathrm{~g} / \mathrm{L}$ PCBs, which meant that the bacteria had the high activity. While Eh first dropped to $300(\mathrm{mV})$ and then maintained 


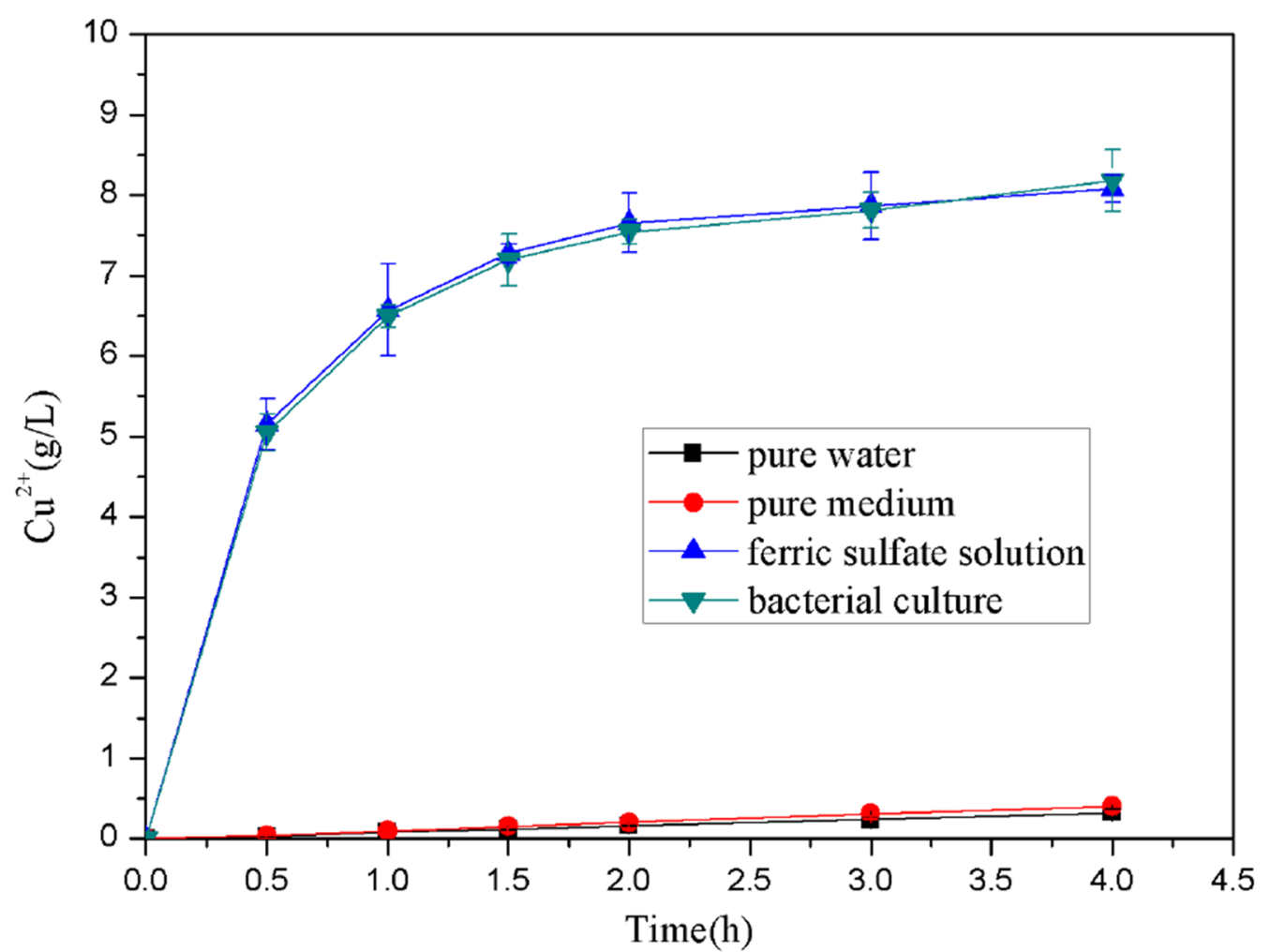

Fig. 3 Time period evaluation of $\mathrm{Cu}^{2+}$ concentration at the conditions of bacteria-free cultural supernatant, ferric sulfate solution, pure water, and pure medium in leaching of copper from PCBs

at about $400(\mathrm{mV})$ in $15 \mathrm{~g} / \mathrm{L}$ PCBs, which indicated that the activity of bacteria was strongly inhibited by PCBs. This result was confirmed by Fig. 4c. Figure 4c shows that the consumption rate of $\mathrm{Fe}^{2+}$ decreased with the increase amount of PCBs. The biooxidation rate of $\mathrm{Fe}^{2+}$ under different amounts of PCBs is shown in Table 3. Due to the cycle of $\mathrm{Fe}^{2+}$ and $\mathrm{Fe}^{3+}\left(\mathrm{Fe}^{3+}\right.$ reacts with copper to produce $\mathrm{Fe}^{2+}$ ) existed in the process of bioleaching of PCBs, the calculation of the oxidation rate should add the part of $\mathrm{Fe}^{2+}$ which was produced by Eq. (2). The result showed that the bacterial oxidation rate of $\mathrm{Fe}^{2+}$ gradually decreased from $0.5833 \mathrm{~g} / \mathrm{L} \mathrm{h}$ in $0 \mathrm{~g} / \mathrm{L}$ PCBs to $0.1580 \mathrm{~g} / \mathrm{L} \mathrm{h}$ in $15 \mathrm{~g} / \mathrm{L}$ PCBs. It was indicated that the bacterial activity was related to the amount of PCBs. The more the PCBs was added, the lower the bacterial activity. The toxicity of PCBs was responsible for the decline of the oxidation rate. The rate of biooxidation process had been proved to be far slower than that of chemicalleaching process. In addition, it was further slower due to the addition of PCBs.

In bioleaching of sulfide ores, the chemical dissolution rate of sulfide ores by ferric ions was very slow. Therefore, bacteria were required to form biofilm between bacteria and sulfide ore to accelerate the dissolution of sulfide ores. While in bioleaching of PCBs, the copper was easily chemically leached by $\mathrm{Fe}^{3+}$, and the addition of bacteria might not significantly increase the dissolution rate of copper. Instead, the rate of biooxidation was inhibited because of the toxicity of PCBs. Therefore, the strategy which separated the process of bacterial oxidation from bioleaching of PCBs might be a good choice.

\section{The role of pyrite in bacterial oxidation of ferrous ions}

Pyrite was introduced into the process of bacterial oxidation of ferrous ions for the purpose of continuous culture of bacteria. The pyrite performed two major roles: (1) pyrite was used as carrier of bacteria. After finishing the Biooxidation process, the supernatant was removed to leaching copper from PCBs, and the bacteria absorbed on the precipitate could be used to oxidation of $\mathrm{Fe}^{2+}$ again. (2) Pyrite was used as energy source. When $\mathrm{Fe}^{2+}$ in the solution was exhausted, bacteria could gain energy from pyrite. Figure 5 shows the effect of adding $5 \%$ pyrite on biooxidation of $\mathrm{Fe}^{2+}$. The result showed that $15 \mathrm{~g} / \mathrm{L} \mathrm{Fe}$ was oxidized by the mixed bacterial culture in $24 \mathrm{~h}$. This indicated that the activity of bacteria was not affected by the addition of pyrite. Therefore, it was feasible that the pyrite was used as bacterial adsorption carrier. 


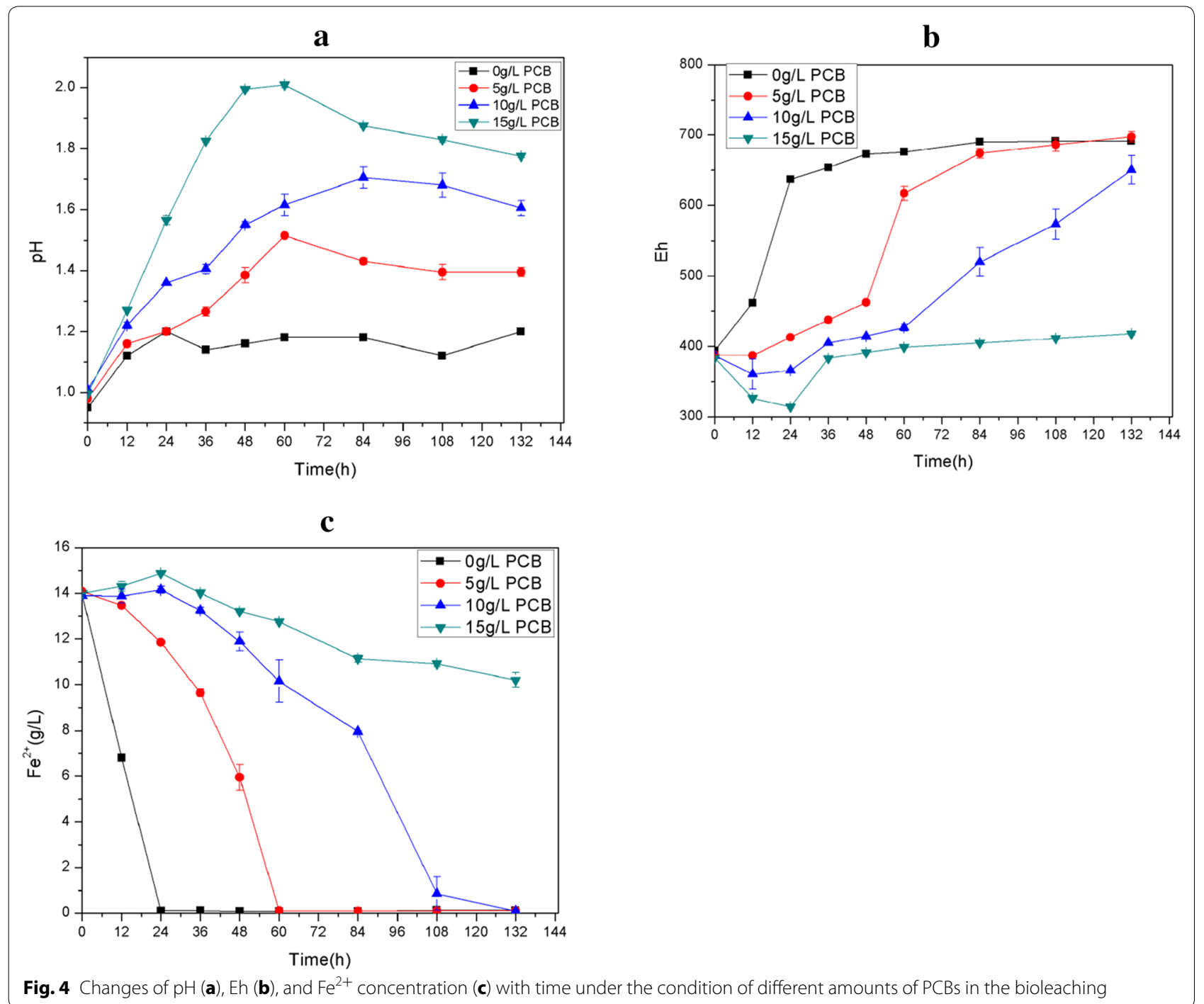

Table 3 Biooxidation rate of $\mathrm{Fe}^{2+}$ on different amounts of PCBs

\begin{tabular}{ll}
\hline PCBs $(\mathbf{g} / \mathbf{L})$ & Biooxidation rate of $\mathrm{Fe}^{\mathbf{2 +}}(\mathbf{g} / \mathbf{L ~ h})$ \\
\hline 0 & 0.5833 \\
5 & 0.3281 \\
10 & 0.2349 \\
15 & 0.1580 \\
\hline
\end{tabular}

The biooxidation-leaching-separation cycle

A biooxidation-leaching-separation cycle which completely isolated bacteria from PCBs was designed. The key point of proving the feasibility of the cycle was whether the activity of the bacteria would be affected by the return of the solution from the separation process.
Therefore, fresh adjusted $9 \mathrm{~K}$ medium was set as control. The results are shown in Fig. 6. It was illustrated that the changes of $\mathrm{pH}, \mathrm{Eh}, \mathrm{Fe}^{2+}$ concentration, and $\mathrm{Fe}^{3+}$ concentration in the solution which returned after a cycle was similar with the control. The result indicated that the activity of bacteria was not affected. Compared to Fig. 4, the separation of bacteria from PCBs was beneficial to avoid the toxic effect of the PCBs on oxidation activity of bacteria. It was also showed that the biooxidation-leaching-separation cycle was feasible.

As the composition of PCBs is complicated and the components of PCBs vary considerably with its origin and manufacturer, it is difficult to analyze all the substances that can affect the oxidation of bacteria in the PCBs. However, it is relatively easy to analyze the effect of some metals which can react with ferric iron and 


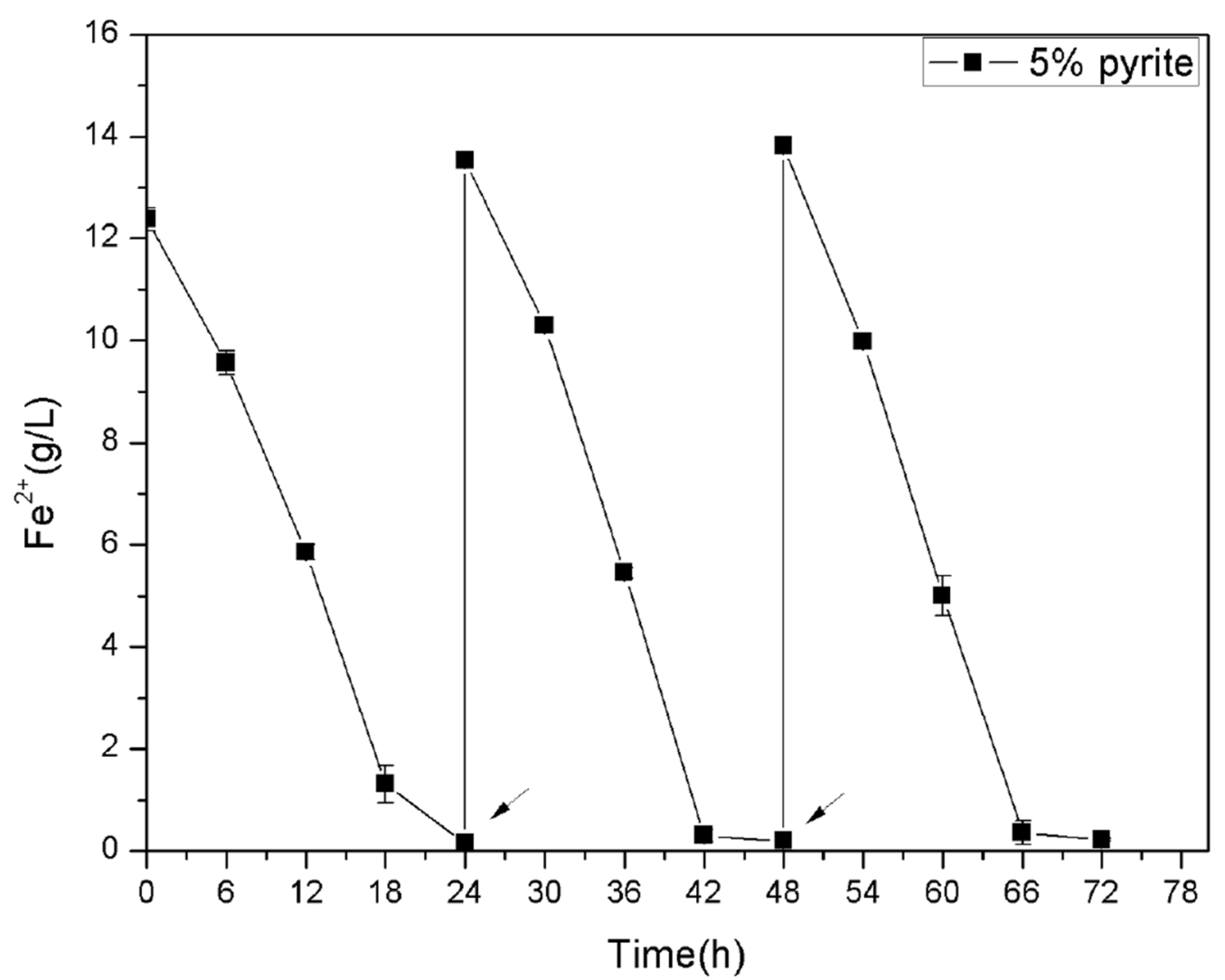

Fig. 5 Effect of $5 \%$ pyrite addition on bacterial oxidation of $\mathrm{Fe}^{2+}$. The arrows mean removing the supernatants and adding fresh adjusted $9 \mathrm{~K}$ medium

occupy a relatively large proportion in PCBs on bacterial oxidation. In this paper, aluminum, zinc, nickel, and copper were selected as models. The reactions were listed as follows:

$$
\begin{aligned}
& 3 \mathrm{Fe}^{3+}+\mathrm{Al} \rightarrow 3 \mathrm{Fe}^{2+}+\mathrm{Al}^{3+} \\
& 2 \mathrm{Fe}^{3+}+\mathrm{Zn} \rightarrow 2 \mathrm{Fe}^{2+}+\mathrm{Zn}^{2+} \\
& 2 \mathrm{Fe}^{3+}+\mathrm{Ni} \rightarrow 2 \mathrm{Fe}^{2+}+\mathrm{Ni}^{2+} .
\end{aligned}
$$

As shown in Fig. 7, it was indicated that the bacterial oxidation was most significantly inhibited by aluminum ion. In addition, there was some inhibition to biooxidation at $5 \mathrm{~g} / \mathrm{L}$ aluminum. When the concentration of zinc ions was within $20 \mathrm{~g} / \mathrm{L}$, the activity of bacteria was not affected. It is shown in Fig. 7b. As shown in Fig. 7c, the inhibition of bacterial oxidation only appeared at $20 \mathrm{~g} / \mathrm{L}$ $\mathrm{Ni}^{2+}$. It was also illustrated that activity of bacteria would be influenced by copper ion at $10 \mathrm{~g} / \mathrm{L}$, as shown in Fig. $7 \mathrm{~d}$.

In this biooxidation-leaching-separation cycle, copper in the solution would be recovered in separation process. While other metals, such as $\mathrm{Al}, \mathrm{Zn}$, and $\mathrm{Ni}$, would be accumulated in the solution with the increase of the cycles. When the metals in the solution accumulated to a line, the activity of the bacteria would be inhibited. Therefore, an important reference for determination of the numbers of the cycle could be provided by studying the effect of metal ions on the activity of bacteria.

\section{Validation test}

With increasing of the cycling number of biooxidationleaching-separation, some toxic and harmful substances would be accumulated in the solution. In addition, the activity of bacteria would be affected. In this paper, $100 \mathrm{~g} / \mathrm{L}$ PCBs was prepared to be leached by the biooxidation-leaching-separation cycle. In addition, the influence of the increase of the cycles on activity of bacteria is shown in Fig. 8. As shown in Fig. 8a, b, the oxidation efficiency of bacteria did not change markedly as the number of cycles increased. The activity of bacteria might be inhibited by the metals which were accumulated with the increase of cycles. In the PCBs used in this paper, aluminum had the highest content except copper. Therefore, even if all the aluminum in the $100 \mathrm{~g} / \mathrm{L}$ PCBs was 

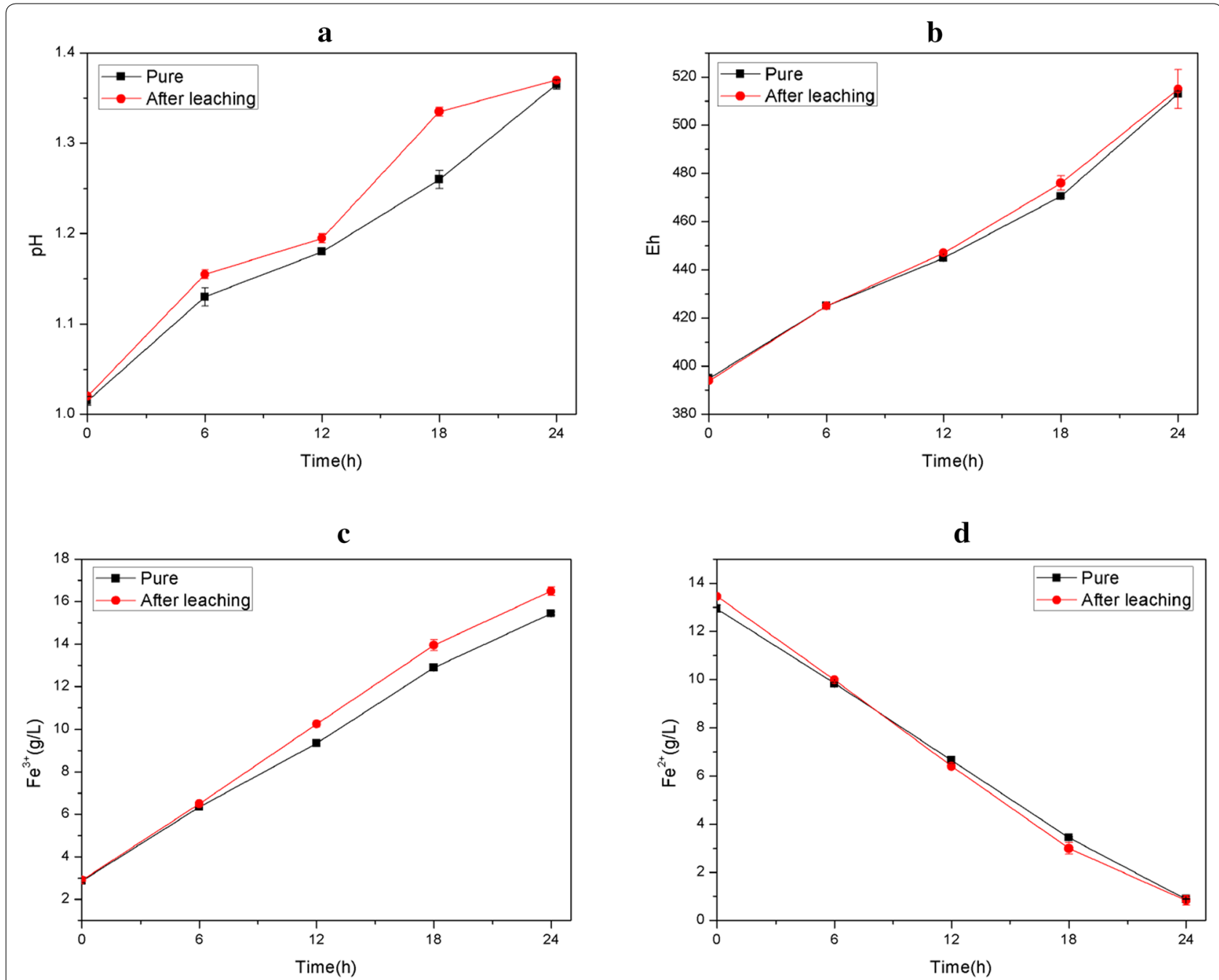

Fig. 6 Variation of $\mathrm{pH}(\mathbf{a})$, Eh (b) $\mathrm{Fe}^{3+}$ concentration $(\mathbf{c})$, and $\mathrm{Fe}^{2+}$ concentration (d) with time under the conditions of pure adjusted 9K Medium and medium returned after one cycle

dissolved into the solution, the content of aluminum was only $0.85 \mathrm{~g} / \mathrm{L}$. In addition, it had not reached the inhibitory concentration to bacteria according to Fig. 7a. The result indicated that the biooxidation-leaching-separation cycles were good enough for reducing the toxic effect of PCBs on bacteria. Figure 8c illustrates the concentration of copper recovered per cycle. There were totally $60.71 \mathrm{~g} / \mathrm{L}$ copper extracted from $100 \mathrm{~g} / \mathrm{L}$ PCBs in 9 cycles. After calculation, a total of $93.4 \%$ of copper was recovered from $\mathrm{PCBs}$ with an average processing capacity of $11.1 \mathrm{~g}$ PCBs $/ \mathrm{L} / \mathrm{d}$. Table 4 shows the comparison of leaching efficiency, condition and capacity in bioleaching of copper from PCBs with those of reference. Although the copper recovery was not the highest, the present study had obvious advantages in the processing capacity of the PCBs.
Various methods were used to reduce the toxicity of PCB to bacterial activity, such as the pretreatment of PCBs (Zhu et al. 2011), the use of adapted bacteria (Arshadi and Mousavi 2015), and the application of two-step process (Bryan et al. 2015). The two-step process was the most commonly used technology to reduce the toxic effect of PCBs (Isildar et al. 2016; Shah et al. 2015; Xiang et al. 2010). In the two-step process, bacteria were first cultivated for a period of time under its optimized conditions to obtain high activity; then, PCBs were added into the culture. The two-step process could improve the leaching efficiency and reduce the leaching time (Xiang et al. 2010; Zhu et al. 2011). As the bacteria in the two-step process had been cultured for a period of time without PCBs, there was high concentration of ferric ion in the solution before the addition of PCBs. This 


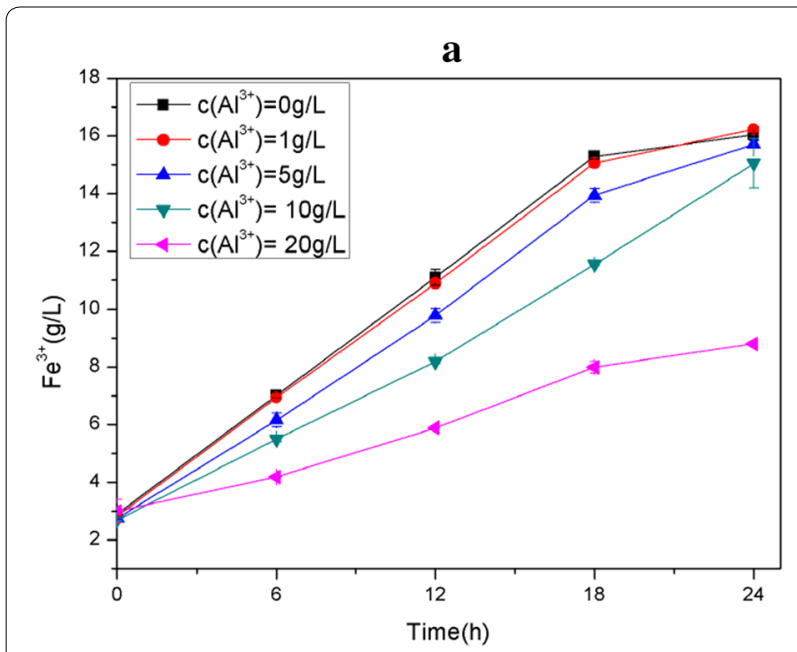

c

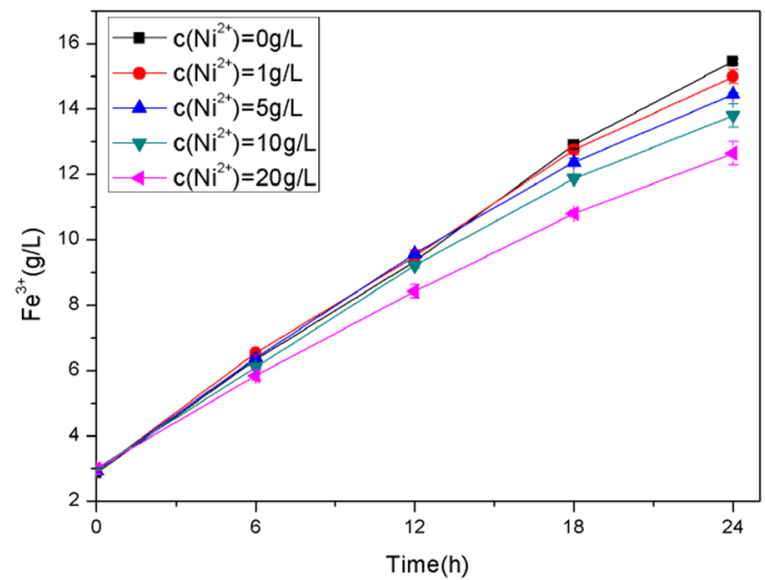

b

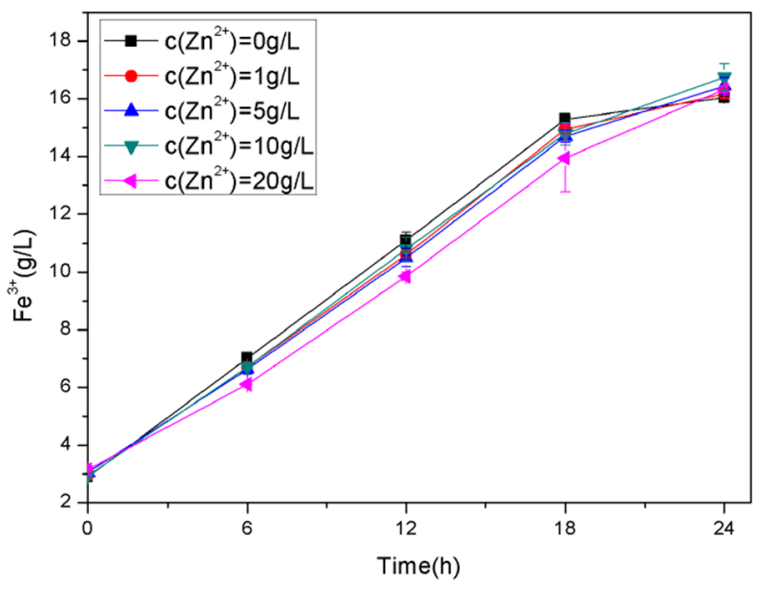

d

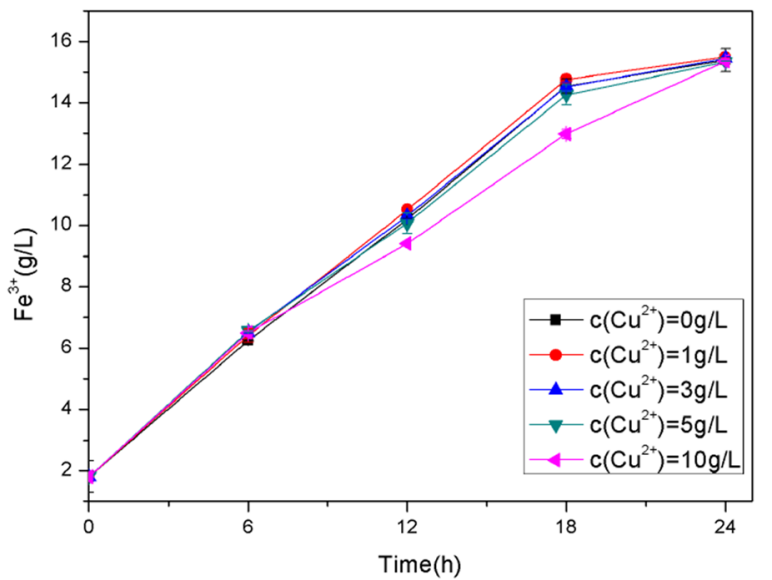

Fig. 7 Influence of $\mathrm{Al}^{3+}$ concentration $(\mathbf{a}), \mathrm{Zn}^{2+}$ concentration $(\mathbf{b}), \mathrm{Ni}^{2+}$ concentration (c), and $\mathrm{Cu}^{2+}$ concentration (d) on biooxidation of ferrous ions by mixed bacteria

was consistent with the idea of using bacterial culture supernatant to leach PCBs in this paper. However, the oxidation activity of bacteria was inevitably affected after the addition of PCBs with the leaching efficiency reduced finally. Probably, the isolation of bacteria from the PCBs was the optimal way to avoid the toxicity of the PCBs. The results of this study also showed that the rate of copper extraction from PCBs increased significantly.

\section{Conclusion}

In the present study, the copper extraction from PCBs was investigated using bacteria-free cultural supernatant. It was demonstrated that about $100 \%$ copper was recovered in $2 \mathrm{~h}$ from $5 \mathrm{~g} / \mathrm{L}$ PCBs. The result indicated that the indirect non-contact mechanism was the predominant mechanism in bioleaching of copper from PCBs. Furthermore, the activity of bacteria was strongly inhibited by the toxicity of PCBs. In addition, the isolation of bacteria from the PCBs probably was the optimal way to avoid the negative effect. A biooxidation-leaching-separation cycle was designed to extract copper from PCBs. In addition, a total of $93.4 \%$ of copper was recovered from $100 \mathrm{~g} / \mathrm{L}$ PCB concentrates in 9 days. Our findings represent a novel type of metal solubilization technique, which may be implemented to develop a three-stage recycle reactor system. Such systems may provide more efficient and cleaner industrial application for the recovery of copper from waste printed circuit boards. 

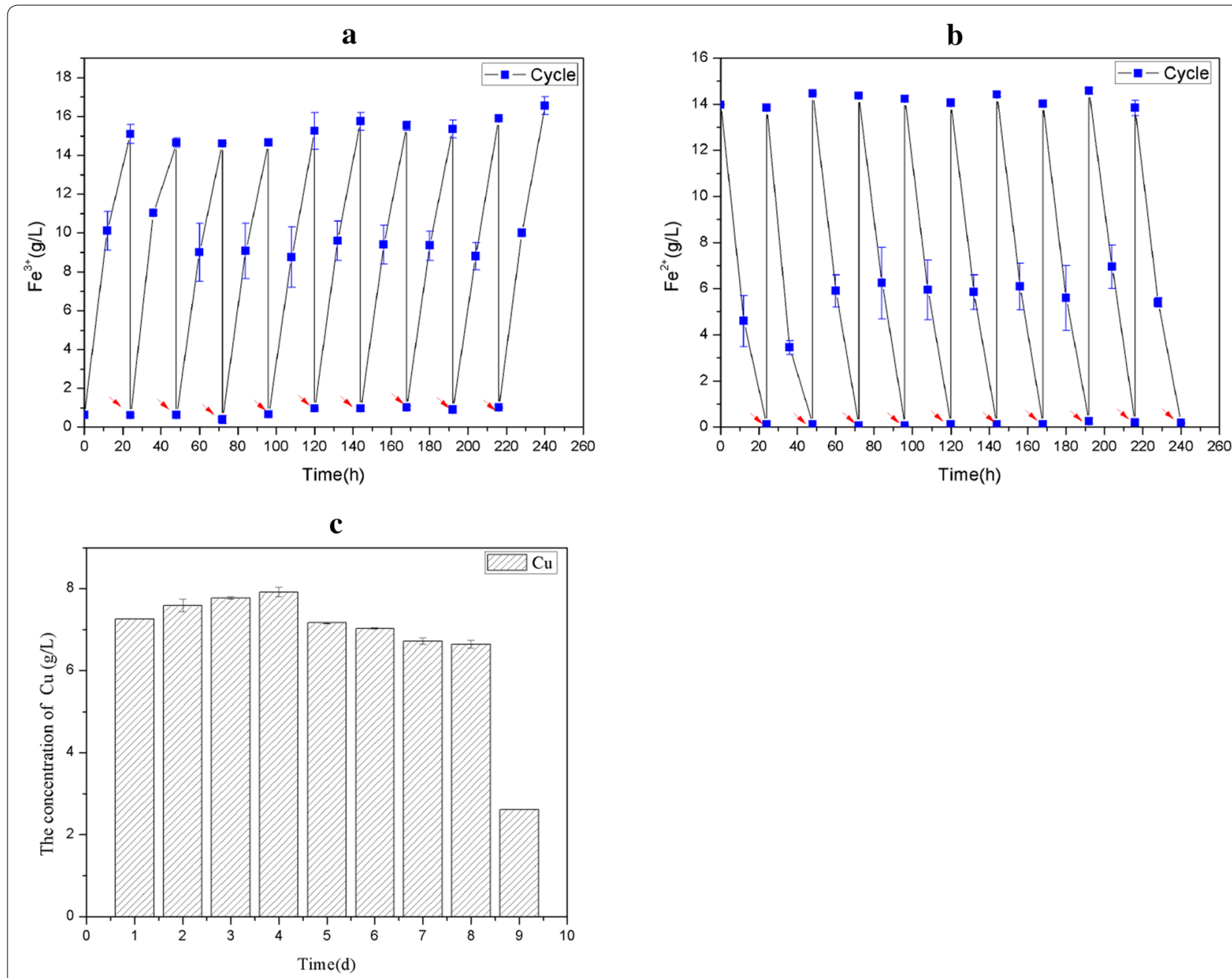

Fig. 8 Influence of the increase of the numbers of cycles on biooxidation process: the variation of $\mathrm{Fe}^{3+}$ concentration $(\mathbf{a})$ and Fe ${ }^{2+}$ concentration (b). The arrows mean the supernatants were removed and mediums after a cycle were returned. In addition, the concentration of copper (c) recovered every day

Table 4 Comparison of leaching efficiency, conditions and capacity in bioleaching of copper from PCBs

\begin{tabular}{lllc}
\hline References & Leaching efficiency (\%) & Conditions & Capacity (gCu/L h) \\
\hline Zhu et al. (2011) & 96.8 & $12 \mathrm{~g} / \mathrm{L} \mathrm{PCBs} \mathrm{concentrates} \mathrm{with} \mathrm{83.8 \%} \mathrm{copper} \mathrm{in} \mathrm{45} \mathrm{h}$ & 0.2235 \\
Yang et al. (2009) & 98.59 & $15 \mathrm{~g} / \mathrm{L} \mathrm{PCBs} \mathrm{with} \mathrm{25.06 \%} \mathrm{copper} \mathrm{in} \mathrm{24} \mathrm{h}$ & 0.1566 \\
Nie et al. (2015) & 96 & $12 \mathrm{~g} / \mathrm{L} \mathrm{PCBs} \mathrm{concentrates} \mathrm{with} \mathrm{63.37 \%} \mathrm{copper} \mathrm{in} \mathrm{7} \mathrm{days}$ & 0.0452 \\
Xiang et al. (2010) & 95 & $20 \mathrm{~g} / \mathrm{L} \mathrm{PCBs} \mathrm{with} \mathrm{23.10 \%} \mathrm{copper} \mathrm{in} \mathrm{5} \mathrm{days}$ & 0.0385 \\
Rodrigues et al. (2015) & 85 & $25 \mathrm{~g} / \mathrm{L} \mathrm{PCBs} \mathrm{with} \mathrm{28.50 \%} \mathrm{copper} \mathrm{in} \mathrm{8} \mathrm{days}$ & 0.0371 \\
Wang et al. (2009) & 99.9 & $7.8 \mathrm{~g} / \mathrm{L} \mathrm{PCBs} \mathrm{with} \mathrm{37.10 \%} \mathrm{copper} \mathrm{in} \mathrm{9} \mathrm{days}$ & 0.0111 \\
Current work & 93.4 & $100 \mathrm{~g} / \mathrm{L} \mathrm{PCBs} \mathrm{concentrates} \mathrm{with} \mathrm{65.0 \%} \mathrm{copper} \mathrm{in} \mathrm{9} \mathrm{days}$ & 0.3006 \\
\hline
\end{tabular}

\section{Authors' contributions}

WT and XZ conceived and designed the experiments. WW and XL performed the experiments and analyzed the data. WW wrote the paper. XZ and MZ revised the manuscript. All authors read and approved the final manuscript.

\section{Acknowledgements}

Not applicable.

\section{Competing interests}

The authors declare that they have no competing interests. 


\section{Availability of data and materials}

All data generated or analyzed during this study are included in the main manuscript file.

\section{Consent for publication}

The authors approved the consent for publishing the manuscript.

\section{Ethics approval and consent to participate}

Not applicable.

\section{Funding}

This study was supported by the Open Project Funding of the State Key Laboratory of Bioreactor Engineering of China and the National High Technology Research and Development Program of China (Nos. 2007 AA060904 and 2012AA061503)

\section{Publisher's Note}

Springer Nature remains neutral with regard to jurisdictional claims in published maps and institutional affiliations.

Received: 6 December 2017 Accepted: 19 February 2018

Published online: 22 February 2018

\section{References}

Arshadi M, Mousavi SM (2014) Simultaneous recovery of Ni and Cu from computer-printed circuit boards using bioleaching: statistical evaluation and optimization. Bioresour Technol 174:233-242

Arshadi M, Mousavi SM (2015) Multi-objective optimization of heavy metals bioleaching from discarded mobile phone PCBs: simultaneous $\mathrm{Cu}$ and Ni recovery using Acidithiobacillus ferrooxidans. Sep Purif Technol 147:210-219

Ballor NR, Nesbitt CC, Lueking DR (2006) Recovery of scrap iron metal value using biogenerated ferric iron. Biotechnol Bioeng 93:1089-1094

Bas AD, Deveci H, Yazici EY (2013) Bioleaching of copper from low grade scrap TV circuit boards using mesophilic bacteria. Hydrometallurgy 138:65-70

Bryan CG, Watkin EL, McCredden TJ, Wong ZR, Harrison STL, Kaksonen AH (2015) The use of pyrite as a source of lixiviant in the bioleaching of electronic waste. Hydrometallurgy 152:33-43

Coram NJ, Rawlings DE (2002) Molecular relationship between two groups of the genus Leptospirillum and the finding that Leptospirillum ferriphilum sp. nov. Dominates South African commercial biooxidation tanks that operate at $40^{\circ} \mathrm{C}$. Appl Environ Microbiol 68:838-845

Dopson M, Bakeraustin C, Koppineedi PR, Bond PL (2003) Growth in sulfidic mineral environments: metal resistance mechanisms in acidophilic micro-organisms. Microbiology 149:1959

Erüst C, Akcil A, Gahan CS, Tuncuk A, Deveci H (2013) Biohydrometallurgy of secondary metal resources: a potential alternative approach for metal recovery. J Chem Technol Biotechnol 88:2115-2132

Hallmann R, Friedrich A, Koops HP, Pommerening-Röser A, Rohde K, Zenneck C, Sand W (1992) Physiological characteristics of and physicochemical factors influence microbial metal leaching. Geomicrobiology 10:193-206

Hong Y, Valix M (2014) Bioleaching of electronic waste using acidophilic sulfur oxidising bacteria. J Clean Prod 65:465-472

Ilyas S, J-C Lee (2014) Biometallurgical recovery of metals from waste electrical and electronic equipment: a review. ChemBioEng Rev 1:148-169

Ilyas S, J-C Lee, R-A Chi (2013) Bioleaching of metals from electronic scrap and its potential for commercial exploitation. Hydrometallurgy 131-132:138-143

Işıldar A, van de Vossenberg J, Rene ER, van Hullebusch ED, Lens PNL (2016) Two-step bioleaching of copper and gold from discarded printed circuit boards (PCB). Waste Manage 57:149-157

Jadhav U, Hocheng H (2013) Extraction of silver from spent silver oxide-zinc button cells by using Acidithiobacillus ferrooxidans culture supernatant. J Clean Prod 44:39-44
Jiang LL, Zhou JJ, Quan CS, Xiu ZL (2017) Advances in industrial microbiome based on microbial consortium for biorefinery. Bioresour Bioprocess 4:11

Jung M, Yoo K, Alorro RD (2017) Dismantling of electric and electronic components from waste printed circuit boards by hydrochloric acid leaching with stannic ions. Mater Trans 58:1076-1080

Kim SD, Baeb J, Chiu PC, Park HS, Cha DK (2005) Bioleaching of cadmium and nickel from synthetic sediments by thiobacillus ferrooxidans. Environ Geochem Health 27:229-235

Liang G, Tang J, Liu W, Zhou Q (2013) Optimizing mixed culture of two acidophiles to improve copper recovery from printed circuit boards (PCBs). J Hazard Mater 250-251:238-245

Liu J, Wu W, Zhang X, Zhu M, Tan W (2017) Adhesion properties of and factors influencing Leptospirillum ferriphilum in the biooxidation of refractory gold-bearing pyrite. Int J Miner Process 160:39-46

Meng L, Wang Z, Zhong YW, Guo L, Gao JT, Chen KY, Cheng HJ, Guo ZC (2017) Supergravity separation for recovering metals from waste printed circuit boards. Chem Eng J 326:540-550

More TT, Yadav JS, Yan S, Tyagi RD, Surampalli RY (2014) Extracellular polymeric substances of bacteria and their potential environmental applications. J Environ Manage 144:1

Mrážiková A, Kaduková J, Marcinčáková R, Velgosová O, Willner J, Fornalczyk A, Saternus M (2016) The effect of specific conditions on $\mathrm{Cu}, \mathrm{Ni}, \mathrm{Zn}$ and Al recovery from PCBS waste using acidophilic bacterial strains. Arch Metall Mater 61:261-264

Nie H, Yang C, Zhu N, Wu P, Zhang T, Zhang Y, Xing Y (2015) Isolation of Acidithiobacillus ferrooxidans strain Z1 and its mechanism of bioleaching copper from waste printed circuit boards. J Chem Technol Biotechnol 90:714-721

Pant D, Joshi D, Upreti MK, Kotnala RK (2012) Chemical and biological extraction of metals present in E waste: a hybrid technology. Waste Manage 32:979-990

Priya A, Hait S (2017) Comparative assessment of metallurgical recovery of metals from electronic waste with special emphasis on bioleaching. Environ Sci Pollut Res Int 24:6989-7008

Robinson BH (2009) E-waste: an assessment of global production and environmental impacts. Sci Total Environ 408:183-191

Rodrigues MLM, Leão VA, Gomes O, Lambert F, Bastin D, Gaydardzhiev S (2015) Copper extraction from coarsely ground printed circuit boards using moderate thermophilic bacteria in a rotating-drum reactor. Waste Manage 41:148-158

Shah MB, Tipre DR, Purohit MS, Dave SR (2015) Development of two-step process for enhanced biorecovery of $\mathrm{Cu}-\mathrm{Zn}-\mathrm{Ni}$ from computer printed circuit boards. J Biosci Bioeng 120:167-173

Silva RA, Park J, Lee E, Park J, Choi SQ, Kim H (2015) Influence of bacterial adhesion on copper extraction from printed circuit boards. Sep Purif Technol 143:169-176

Tian J, Wu N, Li J, Liu Y, Guo J, Yao B, Fan Y (2007) Nickel-resistant determinant from Leptospirillum ferriphilum. Appl Environ Microbiol 73:2364-2368

Vestola EA, Kuusenaho MK, Närhi HM, Tuovinen OH, Puhakka JA, Plumb JJ, Kaksonen $\mathrm{AH}$ (2010) Acid bioleaching of solid waste materials from copper, steel and recycling industries. Hydrometallurgy 103:74-79

Wang J, Bai J, Xu J, Liang B (2009) Bioleaching of metals from printed wire boards by Acidithiobacillus ferrooxidans and Acidithiobacillus thiooxidans and their mixture. J Hazard Mater 172:1100-1105

Xiang Y, Wu P, Zhu N, Zhang T, Liu W, Wu J, Li P (2010) Bioleaching of copper from waste printed circuit boards by bacterial consortium enriched from acid mine drainage. J Hazard Mater 184:812-818

Yang T, Xu Z, Wen J, Yang L (2009) Factors influencing bioleaching copper from waste printed circuit boards by Acidithiobacillus ferrooxidans. Hydrometallurgy 97:29-32

Yang Y, Chen S, Li S, Chen M, Chen H, Liu B (2014) Bioleaching waste printed circuit boards by Acidithiobacillus ferrooxidans and its kinetics aspect. J Biotechnol 173:24-30

Zhu N, Xiang Y, Zhang T, Wu P, Dang Z, Li P, Wu J (2011) Bioleaching of metal concentrates of waste printed circuit boards by mixed culture of acidophilic bacteria. J Hazard Mater 192:614-619 